\title{
The Case Study of Hemoglobin Status: Paint and Chemical Industries Workers Exposed to Organic Acid Anhydrides in S.I.T.E. Area, Kotri, Sindh, Pakistan
}

\author{
Hemoglobin Durumunun Vaka Çalışması: S.I.T.E. Bölgesi, Kotri, \\ Sindh, Pakistan'da Boyama ve Kimyasal Endüstrisinin \\ Çalışanlarının Organik Asit Anhidritlere Maruz Kalması
}

\author{
Research Article \\ Sumera Qureshi ${ }^{*}$, Allah Bux Ghanghro², Muhammad Faisal Qureshi ${ }^{3}$, Tahira Qureshi ${ }^{4}$, \\ Shaista Khan 5 \\ ${ }^{1}$ Dr. M. A Kazi Institute of Chemistry, University of Sindh, Jamshoro, Pakistan. \\ ${ }^{2}$ Institute of Biochemistry, University of Sindh, Jamshoro, Pakistan. \\ ${ }^{3}$ Govt; Ddistrict Hospital, Qasimabad, Hyderabad, Sindh, Pakistan. \\ ${ }^{4}$ Department of Biochemistry, Hacettepe University, Ankara, Turkey. \\ ${ }^{5}$ Medical Research Center, Liaquat University of Medical \& Health Sciences (LUMHS), Pakistan.
}

\section{ABSTRACT}

T

he main objective of this study is to find an association between hemoglobin $(\mathrm{Hb})$ and Organic acid anhydrides (OAAs). The blood protein Hemoglobin $(\mathrm{Hb})$ is influenced after an exposure to environmental hazardous OAAs compounds in paint \& Chemical industry workers occupationally in SITE Area, Kotri, Sindh, Pakistan. A total of 85 workers fulfilled this research study criteria. These workers were divided into two groups like Paint industry $(n=40)$ and chemical industry $(n=45)$ workers. Both worker groups were compared with nonexposed (normal) group for comparative study. The hemoglobin test was done by simple and standard Kit method system on Microlab 300. The data was analysed by using SPSSversion16 software. The mean $\mathrm{Hb}$ for paint industry workers (11.5 \pm 1.4$)$ and chemical industry workers (12.7 \pm 0.7$)$ were lower than non-exposed normal (16.01 \pm 0.1$)$ group. Thus, plasma Hb levels were significantly lower among both worker groups. There is prevalence of anemia found due to lower iron deficiency and poor socio-economic conditions among workers after prolonged harmful chemical compounds exposure.

\section{Key Words}

Hemoglobin ( $\mathrm{Hb})$, adduct, anemia, harmful, workplace exposure, dye industries.

\section{öz}

u çalışmanın temel amacı, hemoglobin $(\mathrm{Hb})$ ve organik asit anhidritler (OAA) arasındaki bağlanmayı bulmaktır. SITE Area, Kotri, Sindh,Pakistan'daki boya ve kimyasal endüstrisinde çalışanların kan proteini olan hemoglobin ( $\mathrm{Hb}$ ), çevre için zararlı OAA bileşiklerine maruz kaldıktan sonra etkilenir. Toplamda 85 çalışan bu araştırma çalışmasına katıldı. Bu çalışanlar boya $(n=40)$ ve kimyasal $(n=45)$ endüstri çalışanları olmak üzere ikiye bölündü. Karşılaştırma çalışması için her iki çalışan grubu maruz kalmayan (normal) grup ile karşılaştırıldı. Hemoglobin testi kolayca ve Microlab 300'daki standart kit metod sistemi ile yapıldı. Elde edilen sonuçlar SPSSversion16 software kullanılarak analiz edildi. Boya (11.5 \pm 1.4$)$ ve kimyasal endüstrisininin çalışanlarının

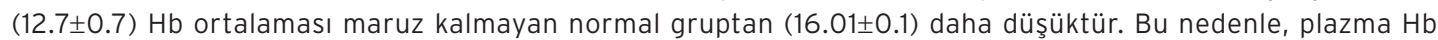
seviyesi her iki grup çalışanlarında da oldukça düşüktür. Bu da uzun süre zararlı kimyasal bileşiklere maruz kalan çalışanlar arasında demir eksikliği ve fakir sosyo-ekonomik durumlardan dolayı anemiyi yaygınlaştırır.

\section{Anahtar Kelimeler}

Hemoglobin $(\mathrm{Hb})$, boya bileşimi, kansızlık, zararlı, işyeri maruzu, boya endüstrileri.

Article History: Received: Apr 2, 2016; Revised: Jun 5, 2016; Accepted: Sep 20, 2016; Available Online: Apr 1, 2017.

Dol: $10.15671 /$ HJBC.2017.158

Correspondence to: S. Qureshi, Dr. M. A Kazi Institute of Chemistry, University of Sindh, Jamshoro, Pakistan. 


\section{INTRODUCTION}

lood protein Hemoglobin ( $\mathrm{Hb}$ ) has many vital functions including oxygen production in human body. It may also get influenced by hazardous environmental compounds and other factors. It was reported in literature $\mathrm{Hb}$ found in higher level $\mathrm{g} / \mathrm{dL}(17 \geq)$ in case of renal and cardiovascular diseases [1,2]. The lower Hb (Iron deficiency) level leads to the prevalence of Anemia approximately 56\% among male adults including women and children [3]. The World Health Organization (WHO) also indicated decreased iron and folic acid levels were found Pakistan's most commonly public health problems [4].

The dyspnea (shortness of breath) and weakness are symptoms of Anemia and the decreased amount of Hemoglobin or R.B.C (red blood cells) in human blood less than $13-14 \mathrm{~g} / \mathrm{dL}$ may cause anemia among male adults. Although in women it was less than $12-13 \mathrm{~g} / \mathrm{dL}$ and according to WHO different ranges are given in Table 1 gender wise [5].

Table 1. Hemoglobin amount $(\mathrm{g} / \mathrm{dL})$ in different age groups (gender wise) for anemia.

\begin{tabular}{ll}
\hline Age (gender group) & $\mathrm{Hb}$ threshold $(\mathrm{g} / \mathrm{dL})$ \\
\hline Children (0.5-5.0 yrs) & 11.0 \\
\hline Children (5-12 yrs) & 11.5 \\
\hline Teens (12-15 yrs) & 12.0 \\
\hline $\begin{array}{l}\text { Women (non-pregnant) (> 15 } \\
\text { yrs) }\end{array}$ & 12.0 \\
\hline Women, pregnant & 11.0 \\
\hline Men (> 15 yrs) & 13.0 \\
\hline
\end{tabular}

The harmful organic acid anhydrides (OAAs) compounds exposure to paint and chemical industry workers, SITE Area, Kotri are at high risk for rhinitis, asthma, allergy and skin problems [6]. The chemical hazards of Textile, Paint and Dye industry based upon anhydrides are associated with health issues among exposed workers. Previously, various studies done on hemoglobin adduct structure with Hexahydrophthalic anhydride (HHPA) in vitro reaction was determined by Mass Spectrometry [7]. Such studies were expensive and confirmed the conjugation even at low molar ratios of $\mathrm{Hb}$ protein with HHPA [8]. Some of researchers even formed HHPA adducts with both major plasma proteins like human serum albumin( $\mathrm{HSA}$ ) and Hemoglobin( $\mathrm{Hb})$ in vivo conjugation by time consuming and laborious methods earlier [9]. The Maleic anhydride (M.A) is an active cross linking agent, Diels-Alder reagent and has vast industrial applications [10]. Succinic anhydride hydrolysed in water slightly and has vital role in Kreb's cycle metabolism naturally. It is frequently used in textiles, dye, agrochemicals, pharmaceuticals and paint chemicals. Acetic anhydride is colourless liquid used as an intermediate in almost all of major industries. Maleic anhydride, Succinic anhydride and Acetic anhydride are used in different industries as given in Table 2 [11].

Table 2. Industrial applications of different anhydrides.

\begin{tabular}{ll}
\hline 1. Maleic anhydride (MA) & $\begin{array}{l}\text { Resins (textiles), Pharma- } \\
\text { ceuticals, Pesticides, Lu- } \\
\text { bricants, Plasticizers, Paint } \\
\text { products (in alkyd resin). }\end{array}$ \\
\hline 2. Succinic anhydride (SA) & $\begin{array}{l}\text { Pharmaceuticals, resins } \\
\text { (as hardner), Paint, dyes, } \\
\text { adhesives, Epoxy resins. }\end{array}$ \\
\hline 3. Acetic anhydride (AA) & $\begin{array}{l}\text { As reagent in organic syn- } \\
\text { thesis, Pharmaceuticals (as } \\
\text { in production of aspirin), } \\
\text { Starch industry, Dyes, Pes- } \\
\text { ticides, Plastics, Taxtile. }\end{array}$ \\
\hline
\end{tabular}

They were considered as biomarker for OAAs compounds study with proteins for quantification analysis in blood plasma among exposed workers [12]. Biological monitoring of short term exposure of different anhydrides and were measured by free anhydride acid in urine and plasma with help of derivatizing agents like pentaflurobenzyl bromide reported previously $[13,14]$.

Guniea Pigs and rats were even used for anhydrides impact studies to one of highly toxic anhydride compound like Hexahydrophthalic anhydride (HHPA) adducts with plasma proteins. The gel filtration study of plasma also confirmed binding of that anhydride (HHPA) to major protein serum albumin [15].

The $\mathrm{Hb}$ adducts (complex) with anhydrides were found superior by half life of 120 days after exposure during occupational industry works and that makes it potential for further new studies. The Hemoglobin relationship in paint industry workers exposed to anhydrides by SDS-PAGE 
Electrophoesis study also correlated with previous results. The asthma, hypersensitivity, eye infections and skin allergies were found rampant in majority of paint workers [16]. The However there is not a single report on plasma hemoglobin in exposed workers. Our current study was aimed to assess the amount of $\mathrm{Hb}$ for adverse health effects upon exposed workers by simple standard method on Microlab 300. This hemoglobin measurement from paint and chemical industry workers is useful indicator relating to changes in blood plasma after exposure in workers compared with non-exposed control subjects.

\section{METHODOLOGY}

This study was carried out from AugustSeptember 2014 upon the blood plasma samples of two selected workers population such as paint industry workers $(n=40)$, chemical industry workers $(n=45)$ and non-exposed OAAs control $(n=$ 40) healthy group. Since Phthalic anhydride(PA), Succinic anhydride (S.A), Maleic anhydride (MA), Trimellitic anhydride (TMA) and Acetic anhydride (AA) used frequently in pharmaceuticals, chemical, paint, plastic and textiles industries [17].

The written consent along with questionnaire regarding age, working time period and present health status of exposed workers were recorded. The clinical data of paint industry, chemical industry and normal groups are given in Table 2. The $3 \mathrm{ml}$ blood sample was collected in heparinized (EDTA) tube and stored at $-20^{\circ} \mathrm{C}$ prior to hemoglobin analysis for each group subjects. All reagents and chemicals are of analytical grade obtained from Sigma Chemical and Merck (Germany). The hemoglobin determination was analysed by standard hemoglobin kit method system (Merck, Germany) on Microlab 300.

Table 2. Clinical profiles of paint industry, chemical industry workers exposed to OAAs and normal (non-exposed to OAAs).

\begin{tabular}{lrr}
\hline Groups & N (male) & $\begin{array}{c}\text { Age } \\
\text { (Mean } \pm \text { SEM) }\end{array}$ \\
\hline Paint industry(W) & 40 & $35 \pm 1.5$ \\
chemical industry (W) & 45 & $32 \pm 2.6$ \\
Control (non-exposed) & 40 & $30 \pm 0.1$ \\
\hline Note: SEM stands for Standard error mean.
\end{tabular}

Note: SEM stands for Standard error mean.

\section{RESULTS and DISCUSSION}

According to this conducted study, the mean hemoglobin $(\mathrm{Hb})$ levels were found slightly elevated in case of chemical industry workers as compared with paint industry workers (as given in Table 3 below). Although both of workers observed data shows decreased hemoglobin $(\mathrm{Hb})$ levels as compared with non-exposed normal group. Most of the blood samples did not meet the normal limits less than $14 \mathrm{~g} / \mathrm{dL}$ in males (as shown in graph Figure 1).

Table 3. Hemoglobin status levels (mean) of paint industry, chemical industry workers exposed to OAAs and normal (non-exposed to OAAs).

\begin{tabular}{lrr}
\hline Groups & $N$ (male) & $\begin{array}{r}\text { Hemoglobin } \\
\text { Mean } \pm(\text { SEM) }\end{array}$ \\
& & \\
\hline Paint industry & 40 & $11.5 \pm 1.4$ \\
workers & 45 & $12.7 \pm 0.7$ \\
chemical industry & 40 & $16.01 \pm 0.1$ \\
workers & & \\
Normal (non- & & \\
exposed) & & \\
\hline
\end{tabular}

Note: SEM stands for Standard error mean.

Almost $75 \%$ of samples in workers were found to be affected by anemia by showing low $h$ $\mathrm{Hb}$ values and adverse health impacts after chemicals exposure during work. The workers were influenced by different allergic sensitization with asthma and eczema including smoking may enhance symptoms from many years during work. They may possibly entered through respiratory system(inhalation), skin and converted into the acid form after absorption [18]. The two of main proteins in plasma like Serum albumin (SA) and

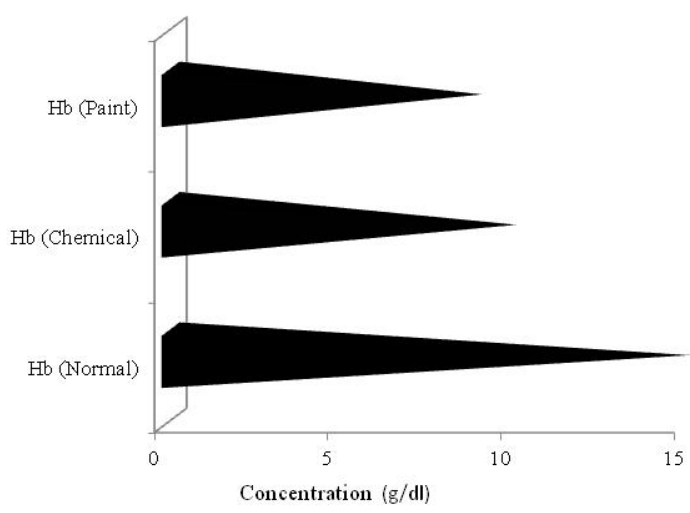

Figure 1. The graph of hemoglobin (mean) of normal (control), chemical industry and paint industry workers. 


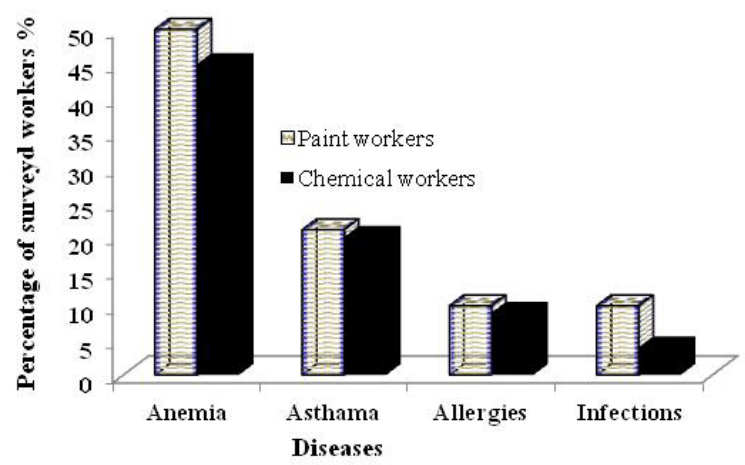

Figure 2. Workers health status via surveyed data.

hemoglobin $(\mathrm{Hb})$ were reported to form adducts with cyclic anhydrides. Those protein adducts (complex) are potential biomarkers with an elevated Immunoglobulins IgE levels among majority of exposed workers corelates with the findings. Since Immunoglobulins IgE was found high in allergy with Rhinitis and Asthma after long-term exposure [19]. Jarvis et al explained the 78 Low molecular weight haptens compounds (including cyclic anhydrides) chemical structures with Nitrogen or Oxygen presence responsible for asthma and allergic Rhinitis [20].

As it was noted by questionnaire that both workers groups had symptoms of eye, skin, respiratory and allergy problems by prolonged exposure to anhydrides. The prevalence of anemia was found high among paint workers .However, very few blood samples among workers population showed normal limits due to various factors. Anemia with lower hemoglobin $(\mathrm{Hb})$ levels also associated with early stages of developing diseases like chronic Kidney disease (CKD), diabetes, cardiovascular and even heart failure in worst conditions [21].

Extensive occupational medical history of all workers $(n=85)$ showed prevalence of anemia was 50\%, 25\% had different allergies, 25\% had asthma and $15 \%$ had infectious diseases like Hepatitis B and C (Figure 2). However, paint workers were in surveyed observed to more incline towards infectious diseases like tuberculosis (T.B) and hepatitis $\mathrm{B}$ and $\mathrm{C}$ than chemical worker group.
This anemia predicament with low Hemoglobin $(\mathrm{Hb})$ values are may be treated by giving iron orally or intravenously with Vit-C (helps Iron absorption) for anemia monitoring monthly in affected workers. The blood transfusions recommended in certain blood loss cases with worst Hemoglobin levels $(6-8 \mathrm{~g} / \mathrm{dL})$. It may even further be able to be evaluated by serum ferritin for more clear iron status in exposed workers to OAAs [22]. We also found the prime clinical symptoms in workers from skin, eyes, upper and lower airways affected [23].

\section{CONCLUSION}

The recent studies showed both of workers paint and chemical industries are affected by hazardous anhydrides after exposure. Further statistical studies revealed the various diseases were more in paint group workers than chemical industry workers. The quality life in workers may improve by safety measures and health follow-ups.

\section{ACKNOWLEDGEMENTS}

The authors are thankful to Institute of Biochemistry, University of Sindh, Jamshoro, for using the Labs to carry out the present research study. Thanks to SITE area industries management and workers of SITE Area, Kotri of industries, for cooperation in providing samples.

\section{References}

1. J.R. Delanghe, M.R. Lanlois, Haptoglobin polymorphism and body iron store, Clin. Chem. Lab. Med., 40 (2002) 212-216.

2. L.Y. Chaur, Iron and atherosclerosis, Proc. NatI Sci. Coun. Repub. China, 24 (2000) 151-555.

3. A. Hall, E. Miguel, Anemia in school children in eight countries in Africa and Asia, Public. Health. Nutr., 4 (2001) 749-756.

4. A.D.B. to pilot project to combat nutritional problems Pakistan. [Online]. 2006 Available $\mathrm{f} \mathrm{r}$ om $: \mathrm{h} \mathrm{t} \mathrm{t} \mathrm{p} \mathrm{:} \mathrm{/} \mathrm{/}$ w w w. a d b . or g / M e d i a / A r t i c l/2006/9538. Pakistan-flourfortification/default.asp.

5. World Health Organization (WHO), Worldwide prevalence of anemia, 1993-2005 (PDF). Geneva: World Health Organization. ISBN 978-92-4-159665-7 (2008).

6. R.D. Barker, J.M. Harris, J.A. Welch, K.M. Venables, A.J.N. Taylor, Occupational asthma caused by tetrachlorophthalic anhydride: a 12-year follow-up, J. Allergy. Clin. Immunol., 101 (1998) 717-719. 
7. M. Kristiansson, B.A.G. Johansson, C.H. Lindh, Mass Spectrometric characterization of human hemoglobin adducts formed in vitro by Hexahydrophthalic anhydride, Chem. Res. Toxicol., 15 (2002) 562-569.

8. C.H. Lindh, B.A.G. Jonsson, Human hemoglobin adducts following exposure to hexahydrophthalic anhydride and methylhexahydrophthalic anhydride, Toxicol. Appl. Pharmacol., 153 (1998) 152-160.

9. G. Johannesson, S. Rosqvist, C.H. Lindh, H. Welinder, B.A.G. Jonsson, Serum albumins are the major site for in vivo formation of hapten-carrier protein adducts in plasma from humans and guinea-pigs exposed to type1 allergy inducing hexahydrophthalic anhydride, Clin. Exp. Allergy., 31 (2001) 1021-1030.

10. J. Dahlin, "Aerosols of Isocynates, Amines and Anhydrides, Sweedish Anhydride Report, (2007) 5282.

11. CHEMSYSTEMS, Maleic anhydride, PERP Report, (2009) 07/08-8.

12. C.H. Lindh, B.A.G. Jonsson, Determination of hexahydrophthalic acid and methylhexahydrophthalic acid in plasma after derivatisation with pentaflurobenzyl bromide using gas chromatography and mass spectrometric detection, J. Chromatogr. 691 (1997) 331-339.

13. B.A.G. Jonsson, S. Skerfving, Toxicokinetics and biological monitoring in experimental exposure of humans to gaseous hexahydrophthalic anhydride, Scand. J. Work. Environ. Health., 19 (1993) 183-90.

14. S. Rosqvist, J. Nielsen, H. Welider, L. Rylander, C.H. Lindh, B.A.G. Jonsson, Exposure-response relationships for hexahydrophthalic and methylhexahydrophthalic anhydrides with total plasma protein adducts as biomarkers, Scand. J. Work. Environ. Health., 29 (2003) 297-303.

15. C.H. Lindh, B.A.G. Jonsson, G. Johannesson, X.D. Zhang, H. Welinder, E.B. Brittebo, Binding of the potent allergen hexahydrophthalic anhydride in the mucosa of the upper respiratory and alimentary tract following single inhalation exposures in guinea pigs and rats, Toxicology, 134 (1999) 153-168.
16. S. Qureshi, S.A. Memon, A.B. Ghanghro, M.F. Qureshi, M.A. Mughal, T. Qureshi, Hemoglobin adducts in paint industry workers: An electrophoretic analysis, Int. J. Adv. Life. Sci., 4 (2014) 208-215.

17. K.M. Venables, Low molecular weight chemicals, hypersensitivity, and direct toxicity: the acid anhydrides, Brit. J. Ind. Med., 46 (1989) 222-32.

18. H. Keskinen, Cyclic acid anhydrides, The Nordic Expert Group for Criteria Documentation of Health Risks from Chemicals and The Dutch Expert Committee on Occupational Standards, 15 (2004) 1-74.

19. A.B. Ghanghro, S. Qureshi, S.A. Memon, F. Qureshi, Total serum immunoglobulin's $E$ levels in chemical industry workers (SITE area, Kotri, Jamshoro) exposed with organic acid anhydrides (OAAs), Brit. J. of Resear., 1 (2014) 120-23.

20. J. Jarvis, M.J. Seed, R. Elton, L. Swayer, R. Agius, Relationship between chemical structure and the occupational asthma hazard of Low molecular weight organic compounds, Occup. Envir. Med., 62 (2005) 243-250.

21. V.M. Hodges, S. Rainey, T.R. Lappin, A.P. Maxwell, Pathophysiology of anemia and erythrocytosis, Crit. Rev. Oncol. Hematol., 64 (2007) 139-158.

22. T.G. Janz, R.L. Johnson, S.D. Rubenstein, Anemia in the emergency department: evaluation and treatment. Emer. Med. Prac., 15 (2013) 1-15.

23. C.B. Mathias, E.J. Freyschmidt, H.C. Oettgen, Immunoglobulin $\mathrm{E}$ antibodies enhance pulmonary inflammation induced by inhalation of a chemical haptene, Clin. Exp. Allergy., 39 (2009) 417-425. 
